Research

Open Access

\title{
Using Food Grade Lye "omushelekha" in the Formulation of Health Products from Commonly Consumed African Indigenous Vegetables and Vegetable Combinations
}

\author{
Mary K Walingo ${ }^{1}$.and Florence O Habwe ${ }^{1}$
}

${ }^{1}$ School of Public Health and Community, Maseno University, Box 333, Maseno Kenya

Corresponding author: Mary K Walingo, PhD, Maseno University, Box 333, Maseno, Kenya

Submission date: March 30, 2011; Acceptance date: May 23, 2011; Publication date: May 24, 2011

\begin{abstract}
:
Background: Lye, sodium hydroxide and potassium hydroxide has been used over the years in food preparation including the preparation of vegetables and dried meat products, washing or chemical peeling of fruits and vegetables, cocoa processing, caramel production, poultry scalding and cooking among others. Lye is believed to improve the organoleptic properties and also enhances the nutritional value to the products.
\end{abstract}

Objective: To assess the effect of food grade lye on the levels of copper and iron in the raw, boiled and boiled-fried single vegetables and vegetable combinations treated with and without food grade lye.

Methods: Single vegetables, Crotalaria occroleuca, Solanum scabrum, Vigna unguiculata and Amaranthus blitum and their combinations were cooled and kept in the fridge at $4^{\circ} \mathrm{Cs}$. Elemental analysis was done for the raw, boiled and boiled-fried samples using Atomic Absorption Spectrophotometry (AAS) under standard conditions using wavelengths of $248.3 \mathrm{~nm}$ for iron and $324.2 \mathrm{~nm}$ for copper. Paired t-test was used to compare the iron and copper levels of the boiled and boiled-fried vegetables while the independent t-test was done to assess the levels of iron and copper in the raw, boiled and boiled fried samples.

Results: Boiled-fried samples recorded higher content of iron and copper than the boiled ones. A combination of Amaranthus blitum-Crotolaria occloreuca boiled without lye boiled-fried with lye, and boiled-fried without lye had the highest copper contents of $1.66 \mathrm{mg} / 100 \mathrm{gram}$, $4.56 \mathrm{mg} / 100 \mathrm{gram}$, and 4.56mg/100gram respectively, compared to Amaranthus blitum alone (3.48mg/100gram) and Crotolaria occloreuca $(0.42 \mathrm{mg} / 100 \mathrm{gram})$. A combination of Amaranthus blitum-Crotolaria occloreuca boiled in non-lye water, and those boiled-fried with and without 
lye had the highest extractable iron of $557 \mathrm{mg} / 100 \mathrm{~g}, 859.2 \mathrm{mg} / 100 \mathrm{~g}$, and $859.2 \mathrm{mg} / 100 \mathrm{~g}$ respectively. Iron content was high in the Solanum scabrum $(281.1 \mathrm{mg} / 100 \mathrm{~g})$, and Crotolaria occloreuca (110/100g), Amaranthus blitum (108mg/100g) boiled-fried with lye. It was possible that iron was leached from the cooking utensils and absorbed by the vegetables.

Conclusion: The results of this study clearly demonstrated that vegetable combinations of Amaranthus blitum-Crotolaria occloreuca had a higher content of copper. Vegetable combinations exposed to different treatments had higher levels of iron and copper. This could be attributed different nutrient-nutrient interactions between different vegetables combinations.

Key Words: Food grade lye, Crotalaria occroleuca, Solanum scabrum, Vigna unguiculata, Amaranthus blitum, iron, copper.

\section{Background}

Copper is an essential nutrient that plays an integral role in the body, acting as a ligand to many proteins and enzymes. The enzyme responsible for the conversion of dopamine to norepineprine which mediates neurologic function requires copper in its structure. Copper helps in the formation of cytochrome oxidase which is a component in oxidative phosphorylation and superoxide dismutase, an antioxidant [1]. The synergistic interaction of copper and iron is crucial in human health. Copper acts as a ligand to ferroxidase II which oxidizes iron, allowing it to be mobilized and transported from hepatic stores to the bone marrow for use in erythropoiesis [2].

Copper deficiency therefore results in excessive iron in the liver but insufficient iron in the bone marrow for effective erythropoiesis [3]. Although copper deficiency is associated with cardiac hypertrophy its association with cardiovascular disease is still currently inconsistent. Copper promotes angiogenesis, stimulates cell proliferation and promotes microtubule formation in cultured saphenous veins (4).

Vegetables have some amount of copper and iron in their raw form which can be improved by combining those vegetables with low levels of iron and copper with those that have higher amounts for improved health benefits to the human body. Food grade lye, sodium hydroxide, has been used over the years in preparation of vegetables and dried meats for a long time with claims of improved nutritional value, and, preventive and curative effects in health conditions. This study seeks to assess the iron and copper levels in selected raw vegetables and their boiled and boiled-fried single vegetables and vegetable combinations, cooked in and without lye water.

\section{Introduction}

Sodium hydroxide has been used in the determination of self-associated 5-caffeollquinic acid and its complexation using UV-Vis spectrophotometry, and found great applications in the extraction alkali metal ions from natural environment. This has been exploited to design the advanced and 
controllable carriers of drugs and food components [5]. 5-caffeolyquinic acid found in vegetables $[6,7,8]$ has health benefits including lowering risks of cardiovascular diseases, cancer, diabetes and other conditions associated with anti-aging [9], through protection against free radicals, free radical mediated inflammation and viral infection $[10,11,12]$.

Effects of pretreatment of sodium hydroxide of three-dimensional poly (1-lactide-coglycolide) scaffolds on adhesion, differentiation, and proliferation of MC3T3-E1 murine preoteoblasts resulted in statistically significant up-regulation of mRNA expression of alkaline phosphatase, bone sialoprotein, osteocalcin, and vascular endothelial growth factor. Sodium hydroxide treatment enhances adhesion and differentiation, slows proliferation, and presents a simple and inexpensive way of improving scaffolds for use in bone tissue engineering [13].

Plant-based complementary foods often contain high levels of phytate, a potent inhibitor of iron, zinc, and calcium absorption [14]. Sodium hydroxide binds phytate making these electrolytes readily available to the body $[15,16]$. In Mexico iron content in vegetables ranged from $0.113 \mathrm{mg} / 100 \mathrm{~g}$ for yogurt to $19.82 \mathrm{mg} / 100 \mathrm{~g}$ for commercial cereals which had minerals added during processing while in some foods copper was not found and the highest content was $3.371 \mathrm{mg} / 100 \mathrm{~g}$ in beef liver [17]. Results of representative samples of 20 standardized Nigerian dishes revealed ranges of iron from $2.28 \mathrm{mg} / 100 \mathrm{~g}$ to $22.10 \mathrm{mg} / 100 \mathrm{~g}$ while copper contents ranged from $0.38 \mathrm{mg} / 100 \mathrm{~g}$ to $1.88 \mathrm{mg} / 100 \mathrm{~g}[18,19]$.

There is scarcity of research articles discussing the problem of copper content in edible parts of vegetable plants $[20,21]$. Copper and iron are involved in the function of several enzymes and are also essential for maintaining life [22, 23]. While copper deficiency is associated with cardiac hypertrophy, its association with cardiovascular disease is inconsistent. Iron complex could prevent cardiovascular disease [24]. This study recognized the role of iron and copper in human health and sought to assess the effect of food grade lye on the levels of copper and iron in selected raw, boiled and boiled-fried single vegetables and vegetable combinations treated with and without food grade lye.

\section{Methods:}

Pods of mature green beans were sun dried for a period of 72 hours, burnt to ashes. This ash was filtered over a special container and the filtrate collected into bottles. This filtrate is the food grade lye that is commonly used in households in the preparation of vegetables and meats over the centuries. Vegetables used in this study were planted at the Maseno University Botanic garden and included: Solanum scabrum, Amaranthus blitum, Crotalaria occloreuca, Vigna unguiculata.

Food grade lye $(15 \mathrm{mls})$ was added to $250 \mathrm{mls}$ of water and brought to boil, and 500 grams of each vegetable species and vegetable combinations (at any time two vegetable samples were combined in a ratio of 1:1, 250 grams of each to make 500 grams) were added to the boiling water and cooked for 10 minutes. This was done for all the four vegetables and the six vegetable combinations to form the category of the boiled samples. For the boiled-fried samples, the same 
procedure was used to boil the vegetables which were then fried in vegetable oil with additions of tomatoes and onions, which may have contributed to the high nutrient levels in the boiledfried samples. For the samples that were not exposed to lye treatment, no food grade lye was added to the boiling water though the procedure followed was the same, for both the boiled and boiled-fried samples.

Samples were cooled and refrigerated at $4^{\circ} \mathrm{C}$. Each sample was oven-dried at $60^{\circ} \mathrm{C}$ for 12 hours then crushed into fine powder using a mill (QCG System LLC Model 4E). The powdered samples were sieved through $125 \mu \mathrm{m}$ apertures BS 410. 0.5g of each sample was weighed and placed in a kjeldahl tube in $20 \mathrm{mls}$ of aqua regia acid $(5 \mathrm{ml} \mathrm{HCl}+5 \mathrm{ml}$ Nitric acid) (Apha, 1985), and heated to boiling for $2 \mathrm{hrs}$ at $96^{\circ} \mathrm{c}$ until the resulting solution was clear and the heating was continued for 30 more minutes. The digested samples were left to cool overnight and the contents were transferred into a $50 \mathrm{ml}$ volumetric flask and made up to the mark with distilled water, and were filtered through a Whatman filter paper No.1. These samples were finally transferred to $100 \mathrm{ml}$ polypropylene bottles, ready for elemental analysis.

Elemental analysis was done on raw, boiled and boiled-fried samples. Atomic Absorption Spectrophotometry (AAS) was used to determine iron and copper contents of each sample. A standard for each element (1000 parts per million) was diluted with $10 \% \mathrm{HCl}$ and aspirated directly using a Narian AAS (Shimadzu AA 6200 Model Japan) at the Mines and Geology Department, Ministry of Natural Resources, Nairobi, Kenya. The spectrophotometer was operated under standard conditions using wavelengths of $248.3 \mathrm{~nm}$ for iron and $324.2 \mathrm{~nm}$ for copper, following Gerge approach (25).

Data on the iron and copper content of the single and vegetable combinations were subjected to independent t-test to determine whether the treatments' effects were significant at $5 \%$ level of significance.

\section{Results:}

Iron content of selected African Indegenous Vegetables (AIVs) and AIV combinations of raw samples was above the normal requirement (Table 1). For all samples boiled-fried in lye water, iron content increased except for Solanum scabrum, Vigna unguiculata, Crotolaria occloreuca, and the combination of Amarathus blitum-Solanum scabrum. Consequently, increase in iron content was only seen in combinations of Vigna unguiculata-Solanum scabrum, Crotolaria occloreuca-Vigna unguiculata, and Crotolaria occloreuca-Amaranthus blitum. Whether the vegetables were cooked as single vegetables or as a combination of two vegetables did not have an effect on their iron solubility. Some vegetables had higher iron content as single vegetables while others had higher content when combined with others. For example, a combination of Amaranthus blitum-Crotolaria occloreuca and Crotolaria occloreuca boiled without lye, boiledfried with lye and boiled-fried without lye had the highest extractable iron of $557 \mathrm{mg} / \mathrm{g}$, $859.2 \mathrm{mg} / \mathrm{g}$, and $859.2 \mathrm{mg} / \mathrm{g}$ respectively compared to Amaranthus blitum and Crotolaria 
occloreuca. However these high levels could be attributed to the leaching of iron in to the vegetables from the iron pots used.

Table 1: A comparison of iron Content $(\mathrm{mg} / \mathrm{lo0g})$ of vegetable and vegetable combinations fried or boiled in lye water and in non-lye water

\begin{tabular}{|l|c|c|c|c|c|}
\hline \multicolumn{1}{|c|}{ AIVs } & Raw & $\begin{array}{c}\text { Boiled } \\
\text { With Lye }\end{array}$ & $\begin{array}{c}\text { Boiled } \\
\text { No Lye }\end{array}$ & $\begin{array}{c}\text { Fried } \\
\text { With Lye }\end{array}$ & $\begin{array}{c}\text { Fried } \\
\text { No Lye }\end{array}$ \\
\hline Solanum scabrum & 17.3 & 12.4 & 11.5 & 281.2 & 401.6 \\
\hline Vigna unguiculata & 24.1 & 20.6 & 15.3 & 16.7 & 1208 \\
\hline Crotolaria occloreuca & 14.7 & 10.7 & 6.4 & 110 & 5.8 \\
\hline Amaranthus blitum & 19.4 & 95.2 & 12.4 & 108 & 5.3 \\
\hline $\begin{array}{l}\text { Solanum scabrum \& } \\
\text { Amaranthus blitum }\end{array}$ & 20.5 & 11.5 & 11.5 & 9.1 & 42.3 \\
\hline $\begin{array}{l}\text { Solanum scabrum\& Crotolaria } \\
\text { cccloreuca }\end{array}$ & 13.2 & 12.2 & 13.9 & 5.1 & 8.2 \\
\hline $\begin{array}{l}\text { Solanum scabrum \& Vigna } \\
\text { unguiculata }\end{array}$ & 23.3 & 69.2 & 200.4 & 381.4 & 6.6 \\
\hline $\begin{array}{l}\text { Amaranthus blitum \& } \\
\text { Crotolaria occloreuca }\end{array}$ & 12.5 & 23.6 & 557.5 & 859.2 & 859.2 \\
\hline $\begin{array}{l}\text { Amaranthus blitum \& Vigna } \\
\text { unguiculata }\end{array}$ & 20.1 & 69.2 & 16.6 & 7.2 & 303 \\
\hline $\begin{array}{l}\text { Crotolaria occloreuca \& Vigna } \\
\text { unguiculata }\end{array}$ & 14.7 & 26.9 & 9.1 & 10.1 & 8.1 \\
\hline
\end{tabular}

Boiled-fried vegetables and vegetable combinations with lye resulted in a significant increase in iron in Solanum scabrum, Crotolaria occloreuca, Amarathus blitum, Solanum scabrum-Vigna unguiculata, Amarathus blitum-Vigna unguiculata. Increase in iron was in single vegetable and vegetable combinations fried without lye for Solanum scabrum, Vigna unguiculata, Crotolaria occloreuca-Amarathus blitum and Amarathus blitum-Vigna unguiculata. There were no significant interactions between cooking method with the vegetables though a combination of Amaranthus blitum-Crotolaria occloreuca had significantly higher iron solubility. Iron solubility was enhanced after frying for all products except for Solanum scabrumAmaranthus blitum, Solanum scabrum-Crotolaria occloreuca and Amaranthus blitum-Vigna unguiculata.

Raw vegetables and vegetable combinations had the least mean iron content compared to the boiled and the boiled-fried ones. Recipes prepared without lye, recorded higher mean iron content for boiled-fried (without lye $284.8 \pm 427$, with lye $272.7 \pm 382.6$ ) compared to mean iron content for boiled (without lye $85 \pm 176$, with lye $30.7 \pm 28.4$ ). The boiled-fried vegetables had 
significantly higher iron content compared to the boiled ones $(\mathrm{P}=0.02)$. There was no significant difference in the mean iron content between vegetables boiled-fried with lye and those boiledfried without lye was insignificant $(\mathrm{P}>0.05)$.

A combination of Amaranthus blitum and Crotolaria occloreuca boiled without lye, boiled-fried with lye, and boiled-fried without lye had the highest copper content of $1.66 \mathrm{mg} / \mathrm{g}$, $4.56 \mathrm{mg} / \mathrm{g}$, and $4.56 \mathrm{mg} / \mathrm{g}$ respectively compared to Amaranthus blitum $(3.48 \mathrm{mg} / \mathrm{g})$ and Crotolaria occloreuca alone $(0.42 \mathrm{mg} / \mathrm{g})$.

Copper content of the raw vegetables and vegetable combinations ranged between 0.16$0.44 \mathrm{mg} / 100 \mathrm{~g}$ (Table 2). Copper content increased for all samples boiled in lye water except for Vigna unguiculata, Solanum scabrum-Amaranthus blitum, Solanum scabrum-Crotolaria occloreuca. For all samples boiled in non-lye water, there was a decrease in the copper content except for Solanum scabrum-Crotolaria occloreuca, Solanum scabrum-Vigna unguiculata, Amaranthus blitum-Vigna unguiculata. Copper content ranged from $0.2-0.56 \mathrm{mg} / 100 \mathrm{~g}$ in all samples boiled in lye water and 0.2-1.66mg/100g for those boiled in non-lye water. Amaranthus blitum-Crotolaria occloreuca boiled in non-lye water recorded an exceptionally high copper content.

Table 2: A comparison of copper content $(\mathrm{mg} / \mathrm{lo0g})$ of vegetable and vegetable combinations fried or boiled in lye water and in non-lye water

\begin{tabular}{|l|c|c|c|c|c|}
\hline \multicolumn{1}{|c|}{ AIVs } & Raw & $\begin{array}{c}\text { Boiled } \\
\text { With Lye }\end{array}$ & $\begin{array}{c}\text { Boiled } \\
\text { No Lye }\end{array}$ & $\begin{array}{c}\text { Fried With } \\
\text { Lye }\end{array}$ & $\begin{array}{c}\text { Fried } \\
\text { No Lye }\end{array}$ \\
\hline Solanum scabrum & 0.44 & 0.52 & 0.34 & 0.98 & $\mathbf{1 . 5 2}$ \\
\hline Vigna unguiculata & 0.16 & 0.16 & 0.6 & 0.1 & $\mathbf{6 . 3 2}$ \\
\hline Crotolaria occloreuca & 0.28 & 0.32 & 0.12 & 0.42 & 0.1 \\
\hline Amaranthus blitum & 0.18 & 0.46 & 0.18 & $\mathbf{3 . 4 8}$ & 0.06 \\
\hline $\begin{array}{l}\text { Solanum scabrum \& } \\
\text { Amaranthus blitum }\end{array}$ & 0.42 & 0.24 & 0.4 & 0.74 & 0.18 \\
\hline $\begin{array}{l}\text { Solanum scabrum \& Crotolaria } \\
\text { occloreuca }\end{array}$ & 0.3 & 0.2 & 0.34 & 0.08 & 0.36 \\
\hline $\begin{array}{l}\text { Solanum scabrum \& Vigna } \\
\text { unguiculata }\end{array}$ & 0.26 & 0.46 & 1.36 & 1.18 & 0.08 \\
\hline $\begin{array}{l}\text { Amaranthus blitum \& } \\
\text { Crotolaria occloreuca }\end{array}$ & 0.34 & 0.36 & 1.66 & $\mathbf{4 . 5 6}$ & $\mathbf{4 . 5 6}$ \\
\hline $\begin{array}{l}\text { Amaranthus blitum \& Vigna } \\
\text { unguiculata }\end{array}$ & 0.16 & 0.46 & 0.2 & 0.7 & 0.6 \\
\hline $\begin{array}{l}\text { Crotolaria occloreuca Vigna } \\
\text { unguiculata }\end{array}$ & 0.28 & 0.28 & 0.18 & 0.14 & 0.1 \\
\hline
\end{tabular}


All vegetables and vegetable combinations boiled-fried in lye water recorded a high copper content except for Vigna unguiculata, Solanum scabrum-Crotolaria occloreuca and Crotolaria occloreuca-Vigna unguiculata. Vegetables and vegetable combinations of Solanum scabrum, Vigna unguiculata, Solanum scabrum-Crotolaria occloreuca, Amaranthus blitumVigna unguiculata, and Amaranthus blitum-Vigna unguiculata boiled-fried in non-lye water had levels of copper below those of raw samples. Recipes prepared without lye had higher mean copper content for boiled-fried samples compared to boiled ones. Boiled-fried vegetables had significantly higher mean copper content compared to boiled ones $(\mathrm{P}=0.03)$.

\section{Discussion:}

There were no significant interactions between cooking methods with vegetable combination though combination of Amaranthus blitum-Crotolaria occloreuca had significantly higher iron solubility. Apart from Solanum scabrum-Amaranthus blitum, Solanum scabrum-Crotolaria occloreuca and Amaranthus blitum-Vigna unguiculata, all other vegetables had their iron solubility enhanced after frying possibly due to availability of vitamin A in the cooking oil which could increase iron solubility. Whether the vegetables were cooked as single vegetables or as a combination of two vegetables did not have an effect on their iron solubility. Cooking vegetables and vegetable combinations in lye water increased their copper content. Some vegetables recorded higher copper content as single vegetables while others recorded higher copper content as vegetable combinations. Combining vegetables during preparation had different effects on different vegetables in terms of their copper content and this could be attributed to different nutrient-nutrient interactions between different vegetables. Copper and iron deficiency are some of the leading factors to increased risk of developing coronary heart disease. Daily copper intakes of populations has been reported to be insufficient $[18,19]$ and approximately one third of daily diets in Belgium, Canada, UK and the USA are also insufficient $(0.65-1.02 \mathrm{mg})$ [25, 26]. Low intake of copper is frequent in diets and is closely associated with heart disease risk [25]. Consumption of adequate iron and copper in the diet can protect the human body from cancer and cardiovascular diseases.

\section{Conclusion:}

Sodium hydroxide has shown significant effect in increasing copper and iron content of vegetables and vegetable combinations. Iron and copper content increased in fried vegetables and vegetable combinations than in the boiled samples. The results of this study clearly demonstrate a high copper content in the vegetable combinations of Amaranthus blitumCrotalaria occroleuca cooked in lye water. Combining vegetables during preparation have different effects on different vegetables in terms of their copper and iron content.

\section{Competing interests:}

The authors declare that there are no competing interests 


\section{Author's Contributions:}

Mary $\mathrm{K}$ Walingo, $\mathrm{PhD}$, is the principle investigator for this study providing oversight and contributed fundamental conceptualization for the research leading to the writing of the grant proposal and manuscript.

Florence $\mathrm{O}$ Habwe is the principle technologist and analyst who performed all the agronomic and lab work and assisted in writing the manuscript.

\section{Acknowledgements and Funding:}

This study was supported by Maseno University Research Institute. We acknowledge all the panelists who participated in the organoleptic tasting of the food products and all the technical staff at the Foods Lab of Maseno University.

\section{References:}

1. Wu J, Ricker M and Muench J. Copper deficiency as a cause of unexplained hematologic and neurologic deficits in patients with prior gastrointestinal surgery. The Journal of the American Board of Family Medicine. 2006;19:191-194.

2. Turnlund JC. In: Shils M, Olson J, Shike M, editors. Modern nutrition in health and disease. Philadelphia: Lippincott; 1998:241.

3. Fields M, Bureau I, Lewis CG. Ferritin is not an indicator of available hepatic iron stores in anemia of copper deficiency in rats. Clin Chem 1997;43:1457-9.

4. Kang JY. Copper and homocysteine in cardiovascular diseases. Pharmacology and Therapeutics 2011:129;3:321-331

5. Cornard JP, Lapounge C, Dangleterre L, All-Bdelot C. Complexation of lead (II) by chlorogenic acid: experimental and theoretical study. J. Phys. Chem. 2008;A112:12475-12484.

6. Scalbert A, Johnson IT, Saltmarsh M. Polyphenols: antioxidants and beyond. Am. J.Clin. Nutr.2005;81:2155-2175.

7. Dillard CJ and German JB. Photochemical: nutraceutical and human health. J. Agric.Food Chem.. 2000;80:1744-1756

8. Prior RL. Fruits and vegetables in the prevention of cellular oxidative damage. Am. J. Clin. Nutr. 2003;78:5705-5785.

9. Carpizo Kh, Saran MJ, Huang W, Ishida K, Roostaeian J, Bischoff D, Huang CK, Rudkin GH, Yamaguchi DT, Miller TA. Pretreatment of poly(l-lactide-co-glycolide) scaffolds with sodium hydroxide enhances osteoblastic differentiation and slows proliferation of mouse preosteoblast cells. Plast Reconstr Surg. 2008;121(2):424-34.

10. Belay A. Determination of self-associated 5-caffeoylquinic acid and its complexation with sodium hydroxide using UV-Vis spectroscopy. Int.J. Phys.Sci 2010;5;5:459-464 
11. Rice-EvansCA, Miller NJ, Paganga G. Structure anti-oxidant activity relationship of flavonoids and phenolic acids. Free Radical Biol. Med. 1996;20:933-956.

12. Kono $Y$, Kobayashi K, Tagawa S, Adachi K, Ueda A, Sawa Y, Shibate H. Antioxidant activity of polyphenolics in diet, rate constant reaction of chloregenic acid and caffeic acid with reactive species of oxygen and nitrogen. BioChim. BioPhys.Lett. 1997;408:221-225.

13. Chandra S, Prasad DA, Krishna N. Effect of sodium hydroxide treatment and/or extrusion cooking on the nutritive value of peanut hulls. 1985;3:187-194.

14. Gibson RS, Bailey KB, Gibbs M, Ferguson EL. A review of phytate, iron, zinc, and calcium concentrations in plant-based complementary foods used in low-income countries and implications for bioavailability. Food Nutr Bull. 2010;31(2 Suppl):S134-46.

15. Champagne ET and Fischer MS. Binding differences of Zinc(11) and $\mathrm{Cu}(11)$ ions with phytate. Journal of Inorganic Biochemistry, 1990;38(3):217-223.

16. Persson H, Turk M, Nyman M, Sandberg AS. ,Binding of $\mathrm{Cu}^{2+}, \mathrm{Zn}^{2+}$, and $\mathrm{Cd}^{2+}$ to Inositol Tri-, Tetra-, Penta-, and Hexaphosphates. J. Agric. Food Chem., 1998;46 (8), pp 3194-3200. DOI: 10.1021/jf971055w

17. Lopez P, Castaneda M, Lopez G, Munoz E, Rosado JL. Iron, zinc and copper content of foods commonly consumed in Mexico. Arch Latinoam Nutr. 1999;49(3):287-94

18. Onianwa PC, Adeyemo AO, Idowu OE and Ogabiela EE. Copper and zinc contnets of Nigerian foods and estimates of the adult dietary intakes. Food Chemistry,2000;72(2001):8995.

19. Onabanjo OO and Oguntona CRB. Iron, Zinc Copper and Phytate content of Standardized Nigerian dishes. Journal of Food Composition and Analysis 2003;16(6): 669-676 doi:10.1016/S0889-1575(03)00063-2

20. Bosiacki M and Tyksinski W. Copper, zinc, iron and manganese content in edible parts of some fresh vegetables sold on markets on Poznan. J Elementol. 2009;14(1):13-22.

21. Kies C. Copper, manganese and cobalt in foods on the Swedish market, 1983-1990. J.Food Compos. Anal., 1989:6(3):223-241.

22. Klevay LM. Cardiovascular disease from copper deficiency-a history. J. Nutr., 2000.;130:489S-492S.

23. Haber A, Aviram M and Gross Z. Protecting the beneficial functionality of lipoproteins by 1Fe, a corrole-based catalytic antioxidant. Chem. Sci., 2011;2:295. DOI:10.1039/c0sc00448k.

24. Gerge C., (ed.) (1984). Analysis of foods and Beverages Modern Technologies. Accademic Press. INCI

25. Klevay LM, Buchet JP, Bunker BE, Clayton RS, Gibson RS, Medeiros DM, Moser-Veillon PB, Patterson KY, Taper LJ, Wolf WR. Copper in the Western diet (Belgium, Canada, U.K and USA). In: Trace Elements in Man and Animals- TEMA 8, M.Anke, D.Meissner, and CF Mills, eds., (1998) Verlag Media Touristik, Gersdorf, Germany. PP. 207-210.

26. Klevay LM and Medeiros DM. deliberations and evaluations of the approaches, endpoints and paradigms for dietary recommendations about copper. J. Nutr., 1996;126:2419S-2426S. 